\title{
A Chemoenzymatic Route to the (+)-Form of the Amaryllidaceae Alkaloid Narseronine*
}

\author{
Shuxin Yang, ${ }^{\mathrm{A}}$ Martin G. Banwell, ${ }^{\mathrm{A}, \mathrm{B}}$ Anthony C. Willis, ${ }^{\mathrm{A}}$ \\ and Jas S. Ward ${ }^{\mathrm{A}}$ \\ A Research School of Chemistry, Institute of Advanced Studies, The Australian National \\ University, Canberra, ACT 2601, Australia. \\ ${ }^{B}$ Corresponding author. Email: martin.banwell@anu.edu.au
}

\begin{abstract}
The enzymatically derived and enantiopure cis-1,2-dihydrocatechol 1 has been converted, over 14 one-pot operations, into the (+)-form of the alkaloid narseronine (2). The present study, which complements earlier work that established a route from metabolite 1 to enantiomer (-)-2, involves an $N$-bromosuccinimide/tri- $n$-butyltin hydride-mediated cyclisation reaction to construct the unsaturated B-ring lactone of the target compound.
\end{abstract}

Manuscript received: 26 August 2014.

Manuscript accepted: 7 September 2014.

Published online: xx xxxxx xxxx.

\section{Introduction}

cis-1,2-Dihydrocatechols such as $\mathbf{1}$ are readily obtained in enantiomerically pure form (viz. $>99.8 \%$ ee) through the whole-cell biotransformation of the corresponding arene (bromobenzene in this case) using mutant forms of bacteria that produce toluene dioxygenase (TDO), the enzyme responsible for this fascinating conversion. ${ }^{[1,2]}$ Metabolites such as $\mathbf{1}$ have proved to be particularly effective starting materials for the chemical synthesis of a remarkably diverse range of chiral,

10 non-racemic natural products and/or biologically active compounds. ${ }^{[2]}$ However, an ongoing issue associated with this (chemoenzymatic ${ }^{[3]}$ ) approach to the construction of such target systems is the seeming confinement of it to the generation of a single enantiomeric form of a given target molecule. ${ }^{[4]}$ As part

15 of an effort to address such constraints, Hudlicky and his coworkers demonstrated that the 'latent' symmetry elements associated with compound 1 and certain of its congeners ${ }^{[2 \mathrm{a}, \mathrm{d}]}$ allow their use in the enantiodivergent synthesis of, inter alia, cyclitols. $^{[5]}$ Similarly, we have shown that various cis-1,220 dihydrocatechols can participate in a range of Diels-Alder cycloaddition processes that permit the assembly of either enantiomeric form of certain polycyclic frameworks, including those associated with sesquiterpenoid natural products. ${ }^{[6]}$ In a related vein, we now detail the outcomes of a study that has culminated in the identification of a method for the assembly of the $(+)$-form of the Amaryllidaceae alkaloid narseronine $(\mathbf{2})^{[7]}$ from compound $\mathbf{1}$, work that complements our recently reported synthesis ${ }^{[8]}$ of its optical antipode [viz. (-)-narseronine] from the same starting material (Chart 1).

The key features of our previously reported synthesis of $(-)$-narseronine [(-)-2] involved the initial conversion (Scheme 1) of metabolite $\mathbf{1}$ into the well-known derivative $\mathbf{3}$ $(95 \%),{ }^{[5]}$ which was itself engaged in selective epoxide ringopening on treatment with the anion derived from acetonitrile.

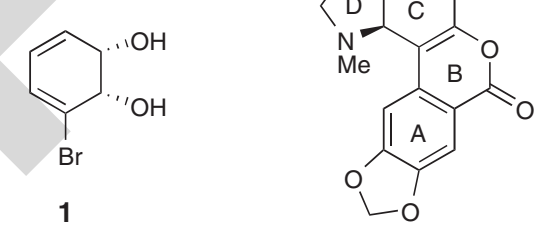

$(+)-2$

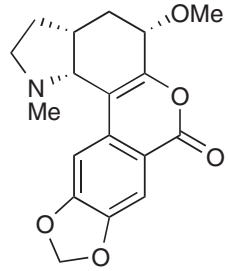

$(-)-2$
Chart 1.

The product alcohol $4(96 \%)^{[9]}$ was then deoxygenated using the Barton-McCombie protocol ${ }^{[10]}$ so as to afford the bromoalkene $5(82 \%)$ that participates in a Suzuki-Miyaura crosscoupling reaction with the arylboronate $6^{[9]}$ to give compound 7 $(75 \%)$. Various manipulations of this last compound including the Raney-cobalt mediated reduction of the associated nitrile residue ${ }^{[9,11]}$ afforded, over eight steps and in $16 \%$ overall yield, the $\alpha$-arylated cyclohexenone $\mathbf{8}$ carrying a protected secondary amine residue tethered through the $\gamma$-carbon. Finally, treatment of compound 8 with $\left(\mathrm{Ph}_{3} \mathrm{P}\right)_{4} \mathrm{Pd}$ in the presence of dimedone resulted in cleavage of the Alloc group, thus allowing the resulting secondary amine $\mathbf{9}$ (which was not isolated) to undergo an intramolecular hetero-Michael addition reaction/ trans-acylation sequence and thus affording (-)-narseronine $[(-)-1](82 \%)$, the structure of which was secured by singlecrystal X-ray analysis. Unfortunately, the specific rotation for the natural product obtained by Bastida et al. ${ }^{[7]}$ was not reported and so it has not been possible to establish its absolute configuration.

\section{Results and Discussion}

The synthetic route used to effect the conversion $\mathbf{1} \rightarrow(+)-\mathbf{2}$, the focus of the study reported herein, relied, in its early stages

*Dedicated to Des Brown in recognition of his seminal and sustained contributions to the chemistry of heterocyclic compounds 
<smiles>O[C@H]1C=CC=C(Br)[C@H]1O</smiles><smiles>CC1(C)O[C@H]2C(Br)=CC3OC3[C@H]2O1</smiles>

3

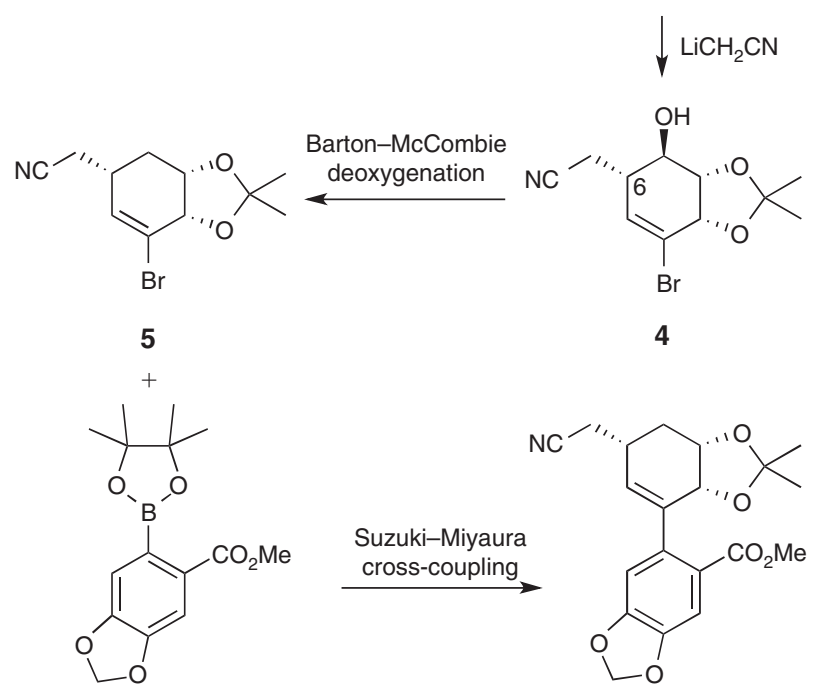

6 7

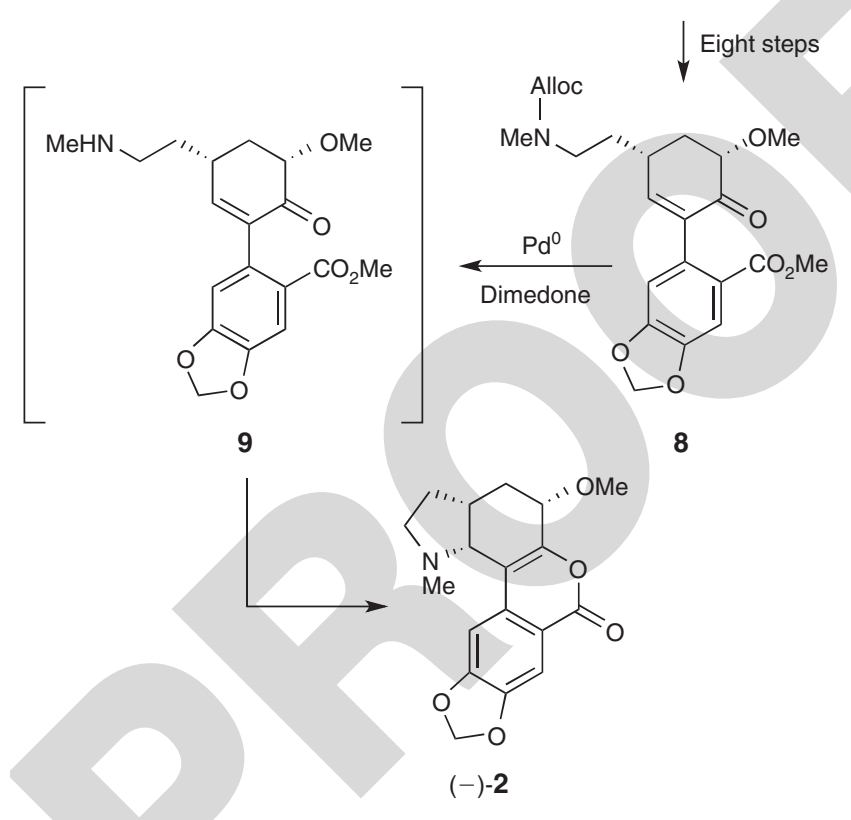

Scheme 1.

(Scheme 2), on chemistry established during the course of preparing the non-natural enantiomeric form of the alkaloid clividine. ${ }^{[12]}$ Specifically, diene $\mathbf{1}$ was treated with $N$ bromosuccinimide (NBS) in wet THF, thus generating, in a completely regio- and diastereo-selective manner, bromohydrin $10,{ }^{[12]}$ which was readily protected as the corresponding acetonide $\mathbf{1 1}^{[12]}$ ( $92 \%$ from 1) under conventional conditions. Successive treatment of compound $\mathbf{1 1}$ with sodium hydride (so as to form the corresponding epoxide) and then the anion of 10 acetonitrile (which was generated in situ by treating acetonitrile itself with $n$-BuLi) afforded the previously reported ${ }^{[12]} \gamma$ hydroxynitrile 12 (87\%). Conversion of compound $\mathbf{1 2}$ into the corresponding methyl xanthate $\mathbf{1 3}^{[12]}(93 \%)$ was achieved under conventional conditions and this was then subjected to a
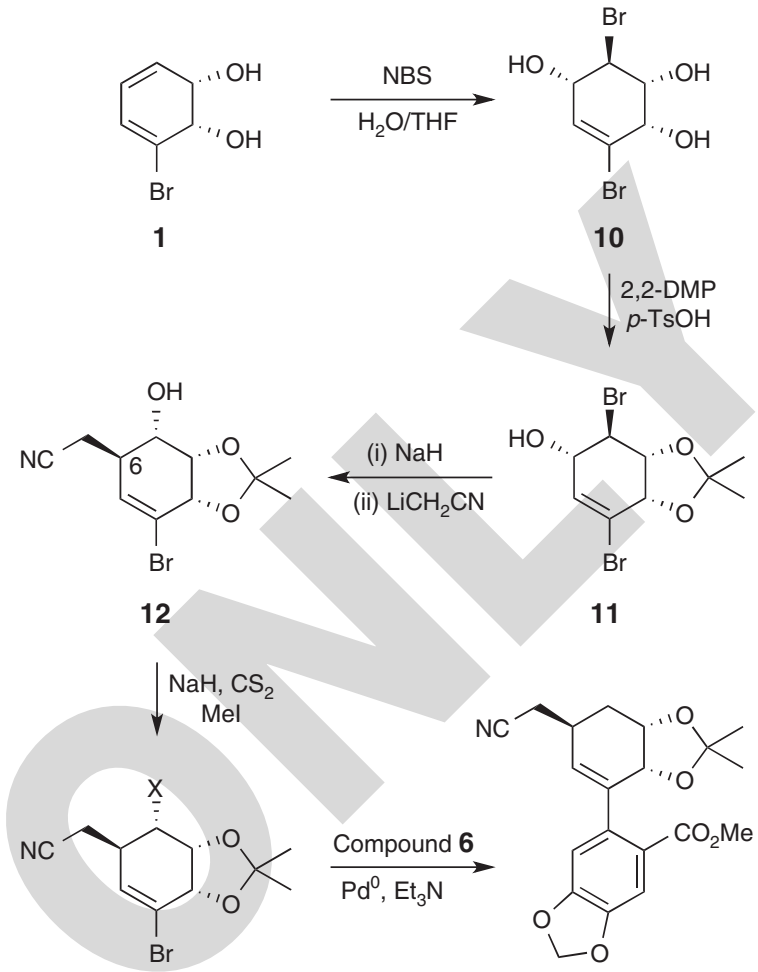

$n-\mathrm{Bu}_{3} \mathrm{SnH}-13[\mathrm{X}=\mathrm{OC}(\mathrm{S}) \mathrm{SMe}]$ AIBN $\longrightarrow 14(\mathrm{X}=\mathrm{H})$

Scheme 2 .

Barton-McCombie deoxygenation reaction using tri- $n$-butyltin hydride and 2,2'-azobis(2-methylpropionitrile) (AIBN) in refluxing benzene, thus generating the deoxygenated congener of alcohol 12, viz. compound 14. ${ }^{[12]}$ This was obtained in $87 \%$ yield. Suzuki-Miyaura cross-coupling of bromoalkene 14 with the arylboronate $6^{[9]}$ proceeded smoothly on using $\mathrm{PdCl}_{2}(\mathrm{dppf})$. $\mathrm{CH}_{2} \mathrm{Cl}_{2}$ in the presence of triethylamine, thereby providing the previously reported compound $\mathbf{1 5}^{[12]}$ in $95 \%$ yield.

The chemistry used to complete the synthesis of (+)narseronine $[(+)-2]$ is shown in Scheme 3 and began with the exposure of the Suzuki-Miyaura cross-coupling product 15 to aqueous acetic acid at $50^{\circ} \mathrm{C}$ such that the allylic hydroxyl group of the initially formed diol reacted with the proximate ester residue to afford the lactone $16(84 \%) .{ }^{[12]}$ The free hydroxyl group within this last compound was protected as the corresponding TBDPS-ether $17^{[12]}(80 \%)$ using conventional conditions and this was, in turn, subjected to reaction with dihydrogen in the presence of Raney-cobalt ${ }^{[13]}$ in ammoniacal methanol to produce the previously reported primary amine $18(82 \%) .{ }^{[12]}$ In a pivotal step of the reaction sequence, this last compound was treated successively with 1.1 molar equivalents of NBS, then, after $0.5 \mathrm{~h}$, with tri- $n$-butyltin hydride $\left(n-\mathrm{Bu}_{3} \mathrm{SnH}\right)$ and AIBN, so affording compound 19 (83\%), which now incorporates the unsaturated B-ring lactone and, therefore, the full polycyclic framework of $(+)$-narseronine $[(+)-2]$.

The exact pathway followed during the conversion $\mathbf{1 8} \rightarrow \mathbf{1 9}$ remains unclear at the present time but it seems likely that the initial step involves the formation of the $\mathrm{N}$-bromo-derivative of the former compound (through halogen atom transfer from $\mathrm{NBS}$ ) and that this derivative reacts with $n$ - $\mathrm{Bu}_{3} \mathrm{SnH}$ to give the corresponding nitrogen-centred radical, which itself engages in a 5-exo-trig cyclisation process to give the tetracyclic benzylic 
<smiles>COc1cc2c(cc1C1=CC(CC#N)CC3OC(C)(C)O[C@H]3C1)OCO2</smiles>

15

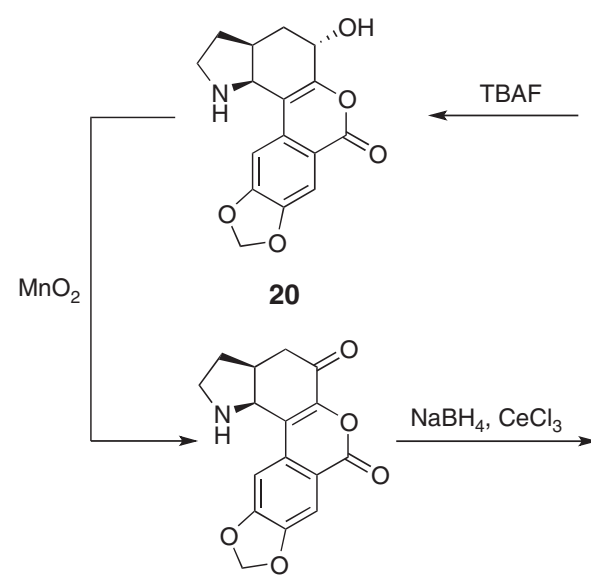

21<smiles>N#CC[C@H]1C=C2c3cc4c(cc3C(=O)O[C@H]2[C@@H](O)C1)OCO4</smiles>

16

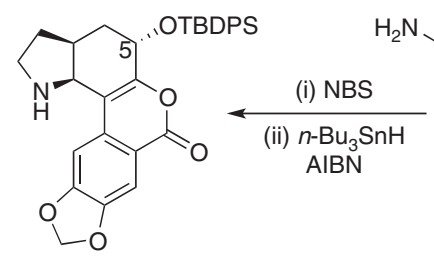

19<smiles>O=c1oc2c(c3cc4c(cc13)OCO4)C1NCCC1CC2O</smiles>

22

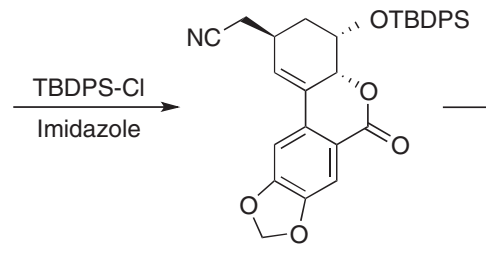

17
$\mathrm{H}_{2}$

Scheme 3.

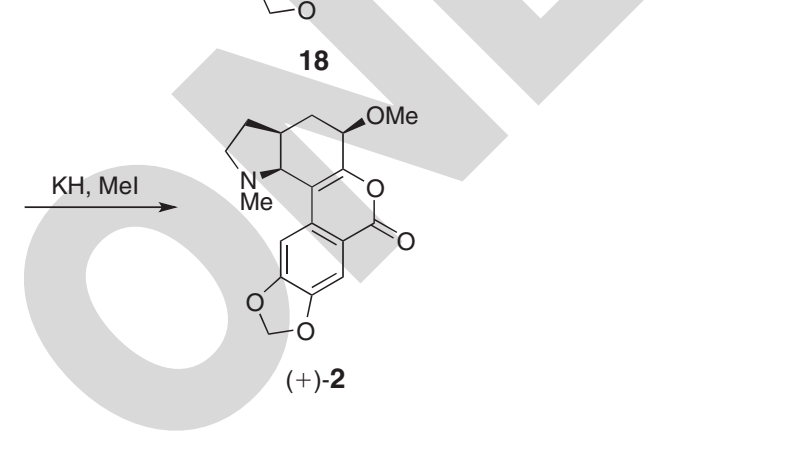

radical. The precise means by which this last species is converted into the final, alkene-containing product remains to be determined but it is conceivable that another bromine atom transfer is involved, thus forming a benzylic bromide that 5 promptly loses the elements of $\mathrm{HBr}$, thereby generating compound 19.

Completion of the synthesis of $(+)$-narseronine $[(+)-2]$ from compound 19 required inversion of configuration at $\mathrm{C} 5$ as well as $\mathrm{N}$ - and $\mathrm{O}$-methylation reactions. The best means of addres-

10 sing the first of these requirements was to cleave the TBDPS ether residue within the latter compound using tetra- $n$-butylammonium fluoride (TBAF) and then oxidising the resulting alcohol 20 (95\%) with $\mathrm{MnO}_{2}$, so forming the ketone $21(78 \%)$. All the ${ }^{1} \mathrm{H}$ and ${ }^{13} \mathrm{C}$ NMR spectral data acquired on products 20

15 and $\mathbf{2 1}$ were in complete accord with the assigned structures but final confirmation of these followed from a single-crystal X-ray analysis on the former compound. The derived ORTEP is shown in Fig. 1 and various crystal data are presented in the Experimental section. Treatment of compound $\mathbf{2 1}$ with the Luche

20 reagent $^{[14]}$ derived from reacting sodium borohydride and $\mathrm{CeCl}_{3}$ heptahydrate in methanol resulted in the essentially exclusive formation of the C5 epimer of compound 20, namely alcohol 22, which was obtained in $99 \%$ yield and the structure of which was also secured by single-crystal X-ray analysis. Presumably, the

25 stereochemical outcome of this 1,2-reduction process derives from the steric impositions of the $\beta$-orientated pyrrolidine ring that ensure hydride is delivered to the $\alpha$-face of the ketone carbonyl unit.

The necessary $\mathrm{N}, \mathrm{O}$-dimethylation of aminoalcohol $\mathbf{2 2}$ so as

30 to generate (+)-narseronine proved to be a remarkably difficult transformation. So, for example, treatment of the former compound with methyl iodide and silver(I) oxide (no solvent) afforded a complex mixture of products from which a small amount of a rather unstable crystalline compound could be

35 obtained. A single-crystal X-ray analysis of this material

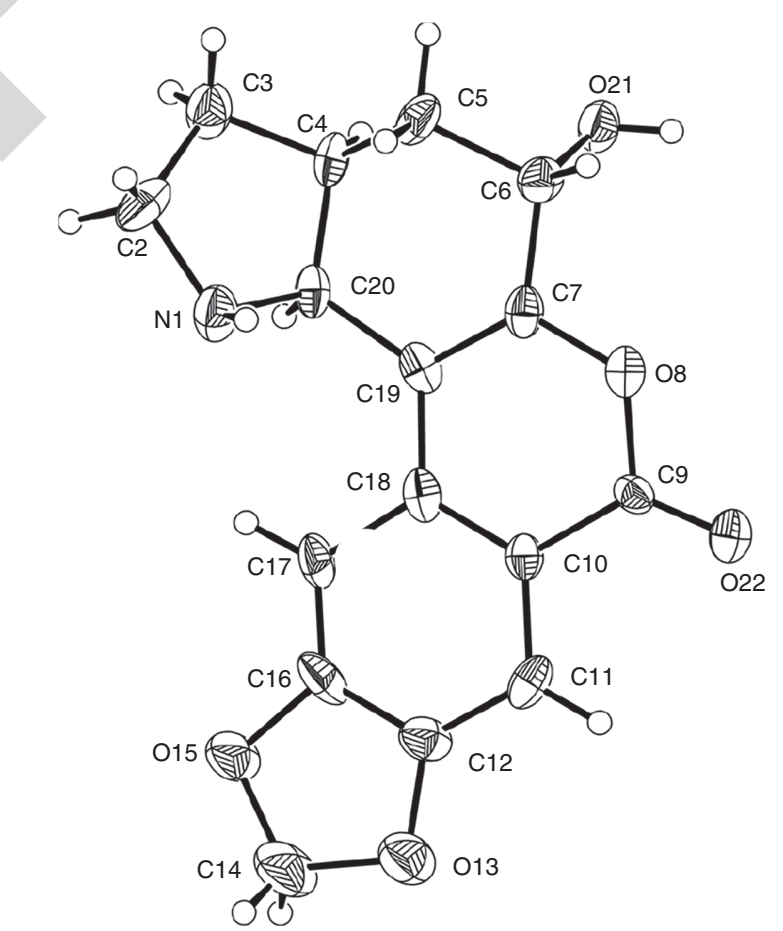

Fig. 1. ORTEP derived from the single-crystal X-ray analysis of compound 20 (CCDC no. 944982) with labelling of selected atoms. Anisotropic displacement ellipsoids display $30 \%$ probability levels. Hydrogen atoms are drawn as circles with small radii.

established that it was the arene hydrate $\mathbf{2 4}$ (Scheme 4). ${ }^{[15]}$ This presumably arises via a two-fold $N$-methylation of substrate 22 to produce the methiodide salt $\mathbf{2 3}$, which itself fragments in the illustrated manner to give, after loss of the elements of hydrogen iodide, the observed product. Eventually, it was established that 

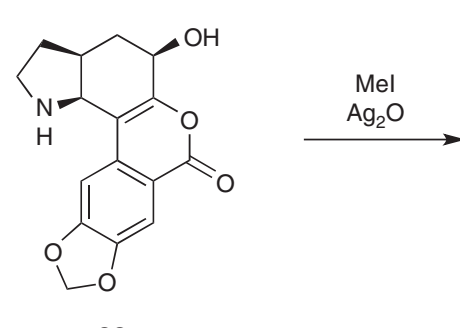

22
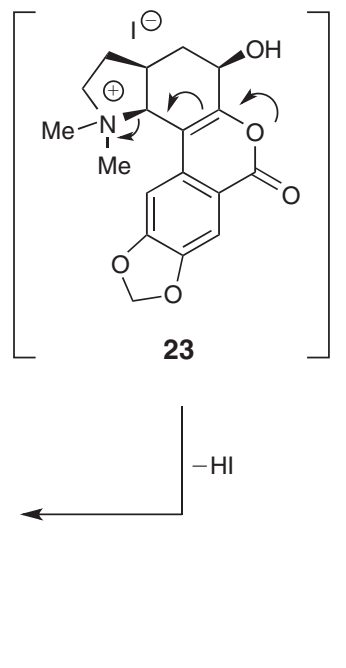

24

Scheme 4 .

when a THF solution of compound 22 maintained at $0-18^{\circ} \mathrm{C}$ was treated with $\sim 4$ molar equivalents of potassium hydride and 8 equivalents of methyl iodide (Scheme 3 ), then a relatively clean $\mathrm{N}, \mathrm{O}$-bismethylation reaction took place, thus finally providing (+)-narseronine [(+)-2] in $83 \%$ yield after chromatographic purification. The ${ }^{1} \mathrm{H}$ and ${ }^{13} \mathrm{C}$ NMR spectral data obtained on this material matched those recorded earlier ${ }^{[8]}$ for its enantiomer but final confirmation of its structure (other than absolute stereochemistry) followed from a single-crystal X-ray analysis.

10 The specific rotation of compound $(+)-2$ was +21.0 (c 0.3 , $\left.\mathrm{CDCl}_{3}\right)$. This compares with the value of $-25.4\left(c 1.6, \mathrm{CDCl}_{3}\right)$ recorded ${ }^{[8]}$ for its enantiomer.

\section{Conclusions}

The ability to effect syntheses of both $(+)$ - and (-)-narseronine

$15[(+)-2$ and (-)-2, respectively] from the cis-1,2-dihydrocatechol 1 serves to further emphasise the utility of such systems as starting materials in chemical synthesis. In this instance, the capacity for enantiodivergence arises by virtue of being able to readily generate the isomeric nitriles 4 and 12 , the

20 C6 stereochemistries of which determine the orientations ( $\alpha$ or $\beta$ ) of the derived pyrrolidine or D-rings in the product enantiomers (-)-2 and (+)-2, respectively. In the case of the reaction sequence leading to the latter form of the title alkaloid, an inversion of configuration at C5 in compound 19 is required.

25 Despite this, the lengths of the two reaction sequences are similar (viz. 14 vs 15 steps), not least because of the more efficient means of introducing the methyl group at nitrogen in the one reported here. Extensions of the chemistries defined above to the assembly of both enantiomeric forms of related

30 alkaloids are now being pursued. Results will be reported in due course.

\section{Experimental}

\section{General Experimental Procedures}

Unless otherwise specified, proton $\left({ }^{1} \mathrm{H}\right)$ and carbon $\left({ }^{13} \mathrm{C}\right) \mathrm{NMR}$ 5 spectra were recorded at $18^{\circ} \mathrm{C}$ in base-filtered $\mathrm{CDCl}_{3}$ on a Varian spectrometer operating at $400 \mathrm{MHz}$ for proton and $100 \mathrm{MHz}$ for carbon nuclei. ${ }^{1} \mathrm{H}$ NMR data are recorded as follows: chemical shift $(\delta)$ [multiplicity, coupling constant(s)
$J(\mathrm{~Hz})$, relative integral] where multiplicity is defined as: $\mathrm{s}=$ singlet; $\mathrm{d}=$ doublet; $\mathrm{t}=$ triplet; $\mathrm{q}=$ quartet; $\mathrm{m}=$ multiplet, or combinations of the above. The signal due to residual $\mathrm{CHCl}_{3}$ appearing at $\delta_{\mathrm{H}} 7.26$ and the central resonance of the $\mathrm{CDCl}_{3}$ 'triplet' appearing at $\delta_{\mathrm{C}} 77.0$ were used to reference ${ }^{1} \mathrm{H}$ and ${ }^{13} \mathrm{C}$ NMR spectra, respectively. Infrared spectra $\left(v_{\max }\right)$ were recorded on a Perkin-Elmer 1800 Series Fourier-transform (FT)IR spectrometer. Samples were analysed as thin films on $\mathrm{KBr}$ plates. Low-resolution electrospray ionisation (ESI) mass spectra were recorded on a Micromass LC-ZMD single quadrupole liquid chromatograph-mass spectrometer whereas highresolution measurements were conducted on an LCT Premier time-of-flight instrument. Low- and high-resolution EI mass spectra were recorded on an Autospec Premier Micromass magnetic-sector machine. Optical rotations were recorded in $\mathrm{CHCl}_{3}$ at $20^{\circ} \mathrm{C}$ on a Perkin-Elmer Model 343 polarimeter using a cell of $1 \mathrm{dm}$ in length. Melting points were measured on an Optimelt automated melting point system and are uncorrected. Analytical thin-layer chromatography (TLC) was performed on aluminium-backed $0.2-\mathrm{mm}$ thick silica gel $60 \mathrm{~F}_{254}$ plates as supplied by Merck. Eluted plates were visualised using a $254 \mathrm{~nm}$ UV lamp and/or by treatment with a suitable dip followed by heating. These dips included phosphomolybdic acid/ceric sulfate/sulfuric acid (conc.)/water (37.5 g:7.5 g:37.5 g: $720 \mathrm{~mL}$ ) or potassium permanganate/potassium carbonate $/ 5 \%$ sodium hydroxide aqueous solution/water $(3 \mathrm{~g}: 20 \mathrm{~g}: 5 \mathrm{~mL}$ : $300 \mathrm{~mL}$ ). Flash chromatographic separations were carried out following protocols defined by Still et al. ${ }^{[16]}$ with silica gel 60 $(40-63 \mu \mathrm{m})$ as the stationary phase and using the AR-or HPLCgrade solvents indicated. Starting materials and reagents were generally available from the Sigma-Aldrich, Merck, TCI, Strem or Lancaster chemical companies and were used as supplied. Drying agents and other inorganic salts were purchased from the AJAX, BDH or Unilab Chemical Companies. Tetrahydrofuran (THF), methanol, and dichloromethane (DCM) were dried using a Glass Contour solvent purification system that is based on a technology originally described by Grubbs et al. ${ }^{[17]}$ Where necessary, reactions were performed under an argon atmosphere.

\section{Specific Synthetic Transformations}

(3aS, 5S, 12cS)-5-[(tert-Butyldiphenylsilyl)oxy]-

2,3,3a, 4, 5, 12c-hexahydro-[1,3]-dioxolo- $\left[4^{\prime}, 5^{\prime}: 6,7\right]$

isochromeno[3,4-g]indol-7 $(1 \mathrm{H})$-one $(19)$

A magnetically stirred solution of amine $\mathbf{1 8}^{[12]}$ (300 mg, $0.55 \mathrm{mmol})$ in degassed benzene $(20 \mathrm{~mL})$ maintained at $18^{\circ} \mathrm{C}$ under an atmosphere of nitrogen was treated, in portions, with NBS (108 mg, $0.61 \mathrm{mmol}, 1.1 \mathrm{~mol}$ equiv.). After a further $0.5 \mathrm{~h}$, the reaction mixture was placed in an oil bath heated at $85^{\circ} \mathrm{C}$, then treated, via syringe pump over $0.83 \mathrm{~h}$, with a solution of tri- $n$-butyltin hydride ( $194 \mu \mathrm{L}, 0.72 \mathrm{mmol}, 1.3 \mathrm{~mol}$ equiv.) and AIBN (11.5 mg, $0.07 \mathrm{mmol}, 0.13 \mathrm{~mol}$ equiv.) in benzene $(5 \mathrm{~mL})$. After a further $2 \mathrm{~h}$, the ensuing mixture was cooled to $18^{\circ} \mathrm{C}$, then concentrated under reduced pressure. The resulting orange oil was subjected to flash chromatography (silica, $2 \% \mathrm{v} / \mathrm{v}$ ammonia-saturated methanol/dichloromethane elution). Concentration of the appropriate fractions $\left(R_{\mathrm{f}} 0.4\right)$ gave compound $19(246 \mathrm{mg}, 83 \%)$ as white foam, $[\alpha]_{\mathrm{D}}^{20}-3.95(c$ 1.0, $\mathrm{CHCl}_{3}$ ). Found: $m / z 540.2206(\mathrm{M}+\mathrm{H})^{+} ; \mathrm{C}_{32} \mathrm{H}_{33} \mathrm{NO}_{5}$ Si requires $540.2206(\mathrm{M}+\mathrm{H})^{+} . \delta_{\mathrm{H}}\left(400 \mathrm{MHz}, \mathrm{CDCl}_{3}\right) 7.75-7.65$ (complex $\mathrm{m}, 4 \mathrm{H}), 7.48-7.21$ (complex m, 8H), $6.04(\mathrm{~m}, 2 \mathrm{H}), 4.42(\mathrm{t}$, $J 3.0,1 \mathrm{H}), 3.96(\mathrm{~d}, J 6.0,1 \mathrm{H}), 3.20(\mathrm{~m}, 1 \mathrm{H}), 3.05(\mathrm{~m}, 1 \mathrm{H}), 2.88$ 
(m, 1H), $2.19(\mathrm{~m}, 1 \mathrm{H}), 1.71(\mathrm{~m}, 1 \mathrm{H}), 1.53(\mathrm{~m}, 2 \mathrm{H}), 1.06(\mathrm{~s}, 9 \mathrm{H})$ (signal due to $\mathrm{N}-\mathrm{H}$ group proton not observed). $\delta_{\mathrm{C}}(100 \mathrm{MHz}$, $\left.\mathrm{CDCl}_{3}\right) 160.9153 .7 \quad 151.9148 .2 \quad 135.9(1), 135.8(7), 134.8$, $133.8,133.2,129.7(1), 129.6(5), 127.7,127.5,116.3,111.2$, 107.3, 103.5, 102.2, 66.7, 56.6, 46.2, 33.7, 32.7, 31.4, 27.0, 19.4 . $v_{\max }(\mathrm{KBr}) / \mathrm{cm}^{-1} 2929,2856,1716,1503,1482,1416,1254$, $1111,1070,1035,937,762 . \mathrm{m} / \mathrm{z}(\mathrm{ESI},+\mathrm{ve}) 562\left([\mathrm{M}+\mathrm{Na}]^{+}\right.$, $6 \%), 540\left([\mathrm{M}+\mathrm{H}]^{+}, 50\right), 267(100)$.

\section{(3aS, 5S, 12cS)-5-Hydroxy-2,3,3a, 4, 5, 12c-hexahydro- $[1,3]$ dioxolo $\left[4^{\prime}, 5^{\prime}: 6,7\right]$-isochromeno[3,4-g]indol- $7(1 \mathrm{H})$-one $(\mathbf{2 0})$}

A magnetically stirred solution of compound $19(215 \mathrm{mg}$, $0.4 \mathrm{mmol})$ in THF $(40 \mathrm{~mL})$ maintained under an atmosphere of nitrogen was cooled to $0^{\circ} \mathrm{C}$, then treated with tetra- $n$ butylammonium fluoride $(0.8 \mathrm{~mL}$ of a $1 \mathrm{M}$ solution in THF, $0.8 \mathrm{mmol}, 2.0 \mathrm{~mol}$ equiv.). The ensuing mixture was warmed to $18^{\circ} \mathrm{C}$, stirred at this temperature for $18 \mathrm{~h}$, then quenched with sodium bicarbonate $(5 \mathrm{~mL}$ of a saturated aqueous solution) and diluted with DCM $(3 \times 10 \mathrm{~mL})$. The combined organic extracts

20 were washed with brine $(3 \times 10 \mathrm{~mL})$ before being dried $\left(\mathrm{Na}_{2} \mathrm{SO}_{4}\right)$, filtered, and concentrated under reduced pressure to afford a light-yellow oil. Subjecting this material to flash chromatography (silica, $4 \% \mathrm{v} / \mathrm{v}$ ammonia-saturated methanol/ dichloromethane) and concentration of the appropriate fractions

$25\left(R_{\mathrm{f}} 0.4\right)$ gave compound $20(114 \mathrm{mg}, 95 \%)$ as white, crystalline solid, $\mathrm{mp} 163^{\circ} \mathrm{C}$. $[\alpha]_{\mathrm{D}}^{20}+82.5\left(\mathrm{c} 1.0, \mathrm{CHCl}_{3}\right)$. Found: $\mathrm{m} / \mathrm{z}$ $302.1027(\mathrm{M}+\mathrm{H})^{+} ; \mathrm{C}_{16} \mathrm{H}_{15} \mathrm{NO}_{5}$ requires $302.1028(\mathrm{M}+\mathrm{H})^{+}$. $\delta_{\mathrm{H}}\left(400 \mathrm{MHz}, \mathrm{CDCl}_{3}\right) 7.33(\mathrm{~s}, 1 \mathrm{H}), 7.17(\mathrm{~s}, 1 \mathrm{H}), 6.06(\mathrm{~s}, 1 \mathrm{H}), 6.03$ $(\mathrm{s}, 1 \mathrm{H}), 4.43(\mathrm{~s}, 1 \mathrm{H}), 3.76(\mathrm{~d}, J 6.0,1 \mathrm{H}), 3.25(\mathrm{~m}, 1 \mathrm{H}), 3.01$ $(\mathrm{m}, 1 \mathrm{H}), 2.69(\mathrm{~m}, 1 \mathrm{H}), 2.13(\mathrm{~m}, 1 \mathrm{H}), 1.90-1.71($ complex m, 2H), $1.59(\mathrm{~m}, 1 \mathrm{H})$ (signals due to $\mathrm{N}-\mathrm{H}$ and $\mathrm{O}-\mathrm{H}$ group protons not observed). $\delta_{\mathrm{C}}\left(100 \mathrm{MHz}, \mathrm{CDCl}_{3}\right) 161.3,153.7,152.3$, $148.1,134.6,115.6,110.9,107.1,103.3,102.3,64.3,56.4$, $46.1,32.7,32.5,31.2$. $v_{\max }(\mathrm{KBr}) / \mathrm{cm}^{-1} 3416,3330,2927$, 35 1706, 1654, 1502, 1483, 1418, 1282, 1255, 1115, 1037. m/z $(\mathrm{ESI},+\mathrm{ve}) 324\left([\mathrm{M}+\mathrm{Na}]^{+}, 13 \%\right) 302\left([\mathrm{M}+\mathrm{H}]^{+}, 22\right), 267$ (100), 242 (60), 241 (48).

\section{(3aS, 12cS)-1,2,3,3a, 4, 12c-Hexahydro-[1,3]dioxolo} $\left[4^{\prime}, 5^{\prime}: 6\right.$, 7] isochromeno[3,4-g]indole-5,7-dione (21)

40 Manganese dioxide ( $455 \mathrm{mg}, 5.2 \mathrm{mmol}, 15 \mathrm{~mol}$ equiv.) was added in one portion to a magnetically stirred solution of alcohol $20(105 \mathrm{mg}, 0.35 \mathrm{mmol})$ in DCM $(25 \mathrm{~mL})$. The ensuing mixture was heated to $30^{\circ} \mathrm{C}$ for $22 \mathrm{~h}$ while being maintained under a nitrogen atmosphere, then cooled to $18^{\circ} \mathrm{C}$ before being filtered through a pad of Celite ${ }^{\mathrm{TM}}$. The filtrate was concentrated under reduced pressure and the resulting brown oil subjected to flash chromatography (silica, $\sim 2-3 \% \mathrm{v} / \mathrm{v}$ ammonia-saturated methanol/dichloromethane). Concentration of the appropriate fractions $\left(R_{\mathrm{f}} 0.5\right)$ gave compound $21(81 \mathrm{mg}, 78 \%)$ as a white solid, $50 \mathrm{mp} 142-143^{\circ} \mathrm{C}$. $[\alpha]_{\mathrm{D}}^{20}+88.8\left(\mathrm{c} 1.0, \mathrm{CDCl}_{3}\right)$. Found: $\mathrm{m} / \mathrm{z}$ $300.0871(\mathrm{M}+\mathrm{H})^{+} ; \mathrm{C}_{16} \mathrm{H}_{13} \mathrm{NO}_{5}$ requires $300.0872(\mathrm{M}+$ $\mathrm{H})^{+} . \delta_{\mathrm{H}}\left(400 \mathrm{MHz}, \mathrm{CDCl}_{3}\right) 7.67(\mathrm{~s}, 1 \mathrm{H}), 7.42(\mathrm{~s}, 1 \mathrm{H}), 6.16$ $(\mathrm{m}, 2 \mathrm{H}), 4.30(\mathrm{~d}, J 4.0,1 \mathrm{H}), 3.32(\mathrm{~m}, 1 \mathrm{H}), 3.15(\mathrm{~m}, 1 \mathrm{H}), 2.90$ (m, 1H), 2.73-2.62 (complex m, 2H), $2.20(\mathrm{~m}, 1 \mathrm{H}), 1.84$ (broad $\mathrm{s}, 1 \mathrm{H}), 1.71(\mathrm{~m}, 1 \mathrm{H}) . \delta_{\mathrm{C}}\left(100 \mathrm{MHz}, \mathrm{CDCl}_{3}\right) 188.7,159.3,153.9$, $150.5,143.1,132.5,124.6,119.3,108.3,104.7,102.8,56.0$, $46.2,39.3,37.4,31.5 \cdot v_{\max }(\mathrm{KBr}) / \mathrm{cm}^{-1} 3349,2931,2876,1714$, $1677,1501,1484,1416,1322,1274,1254,1145,1026 . \mathrm{m} / \mathrm{z}$ $(\mathrm{ESI},+\mathrm{ve}) 621\left([2 \mathrm{M}+\mathrm{Na}]^{+}, 77 \%\right), 599\left([2 \mathrm{M}+\mathrm{H}]^{+}, 99\right), 322$ $60\left([\mathrm{M}+\mathrm{Na}]^{+}, 46\right), 300\left([\mathrm{M}+\mathrm{H}]^{+}, 80\right), 283(100)$.
(3aS, 5R, 12cS)-5-Hydroxy-2,3,3a, 4, 5, 12c-hexahydro$[1,3]$ dioxolo $\left[4^{\prime}, 5^{\prime}: 6,7\right]$-isochromeno[3,4-g]indol-

$7(1 \mathrm{H})$-one $(\mathbf{2 2})$

A magnetically stirred solution of ketone 21 (73 mg, $0.25 \mathrm{mmol})$ and $\mathrm{CeCl}_{3} \cdot 7 \mathrm{H}_{2} \mathrm{O}(92 \mathrm{mg}, 0.38 \mathrm{mmol}, 1.5$ equiv. $)$ in methanol $(10 \mathrm{~mL})$ was cooled to $-78^{\circ} \mathrm{C}$ and, after $0.25 \mathrm{~h}$, treated with sodium borohydride ( $11.3 \mathrm{mg}, 0.03 \mathrm{mmol}, 1.2 \mathrm{~mol}$ equiv.) then, after $0.03 \mathrm{~h}$, with sodium bicarbonate $(2 \mathrm{~mL}$ of a saturated aqueous solution). The resulting mixture was extracted with dichloromethane $(5 \times 10 \mathrm{~mL})$, the combined organic phases were dried $\left(\mathrm{MgSO}_{4}\right)$, filtered, and concentrated under reduced pressure, with the residue thus obtained being subjected to flash chromatography (silica, 96:4 v/v dichloromethane/ammoniasaturated methanol). Concentration of the appropriate fractions $\left(R_{\mathrm{f}} 0.4\right)$ gave compound $22(73 \mathrm{mg}, 99 \%)$ as a white, crystalline solid, mp $168-169^{\circ} \mathrm{C}$. $[\alpha]_{\mathrm{D}}^{20}+83.9\left(\mathrm{c} 1.0, \mathrm{CDCl}_{3}\right)$. Found: $\mathrm{m} / \mathrm{z}$ $302.1031(\mathrm{M}+\mathrm{H})^{+} ; \mathrm{C}_{16} \mathrm{H}_{15} \mathrm{NO}_{5}$ requires $302.1028(\mathrm{M}+\mathrm{H})^{+}$. $\delta_{\mathrm{H}}\left(400 \mathrm{MHz}, \mathrm{CDCl}_{3}\right) 7.57(\mathrm{~s}, 1 \mathrm{H}), 7.34(\mathrm{~s}, 1 \mathrm{H}), 6.10(\mathrm{~m}, 2 \mathrm{H})$, $4.65(\mathrm{dd}, J 12.0,6.0,1 \mathrm{H}), 3.86(\mathrm{~d}, J 3.0,1 \mathrm{H}), 3.32(\mathrm{~m}, 1 \mathrm{H}), 3.05$ (m, 1H), 2.43 (m, 1H), 2.15-2.02 (complex m, 3H), 1.78-1.63 (complex $\mathrm{m}, 2 \mathrm{H}$ ) (signal due to $\mathrm{N}-\mathrm{H}$ group proton not observed). $\delta_{\mathrm{C}}\left(100 \mathrm{MHz}, \mathrm{CDCl}_{3}\right) 161.3,154.1,152.6,148.2$, 135.0, 115.3, 107.4, 103.5, 102.3, 65.9, 57.1, 46.0, 35.7, 33.1, 31.8 (one signal obscured or overlapping). $v_{\max }(\mathrm{KBr}) / \mathrm{cm}^{-1}$ 3316, 2926, 2870, 1709, 1621, 1502, 1481, 1416, 1283, 1256 , $1165,1094,1034 . \mathrm{m} / z(\mathrm{ESI},+\mathrm{ve}) 324\left([\mathrm{M}+\mathrm{Na}]^{+}, 40 \%\right) 302$ $\left([\mathrm{M}+\mathrm{H}]^{+}, 100\right), 241(35)$.

\section{(R)-2-(2-(Dimethylamino)ethyl)-4-hydroxy-3}

4-dihydro-6H-[1,3]dioxolo $\left[4^{\prime}, 5^{\prime}: 4,5\right]$ benzo-[1,2-c] chromen-6-one (24)

A magnetically stirred mixture of compound 22 (42 mg, $0.14 \mathrm{mmol})$ and methyl iodide $(1 \mathrm{~mL}, 16 \mathrm{mmol})$ maintained under a nitrogen atmosphere at $18^{\circ} \mathrm{C}$ was treated with silver(I) oxide $(323 \mathrm{mg}, 1.4 \mathrm{mmol})$ and the resulting mixture stirred in a sealed tube at $50^{\circ} \mathrm{C}$ for $16 \mathrm{~h}$ before being cooled, filtered, and concentrated under reduced pressure. The resulting yellow oil was subjected to flash chromatography (silica, $95: 5 \rightarrow 90: 10$ $\mathrm{v} / \mathrm{v}$ dichloromethane/ammonia-saturated methanol gradient elution) and concentration of the relevant fractions $\left(R_{\mathrm{f}} 0.3\right.$ in $90: 10 \mathrm{v} / \mathrm{v}$ dichloromethane/ammonia-saturated methanol) gave an unstable oil $(30 \mathrm{mg})$, a portion of which crystallised on standing. A crystal of this material was subjected to singlecrystal X-ray analysis and this revealed it to be compound 24 . The very small quantities of compound $\mathbf{2 4}$ obtained by this means precluded the acquisition of any other spectral data.

\section{(3aS, 5R, 12cS)-5-Hydroxy-2,3,3a, 4,5,12c-hexahydro- $[1,3]$ dioxolo- $\left[4^{\prime}, 5^{\prime}: 6,7\right]$ isochromeno[3,4-g]indol- \\ $7(1 \mathrm{H})$-one $[(+)-2,(+)$-Narseronine $]$}

A magnetically stirred solution of alcohol $22(18.6 \mathrm{mg}$, $0.06 \mathrm{mmol})$ in dry THF $(2 \mathrm{~mL})$ maintained at $0^{\circ} \mathrm{C}$ under a nitrogen atmosphere, was treated, in portions, with potassium hydride (32 mg of a $30 \%$ dispersion in mineral oil, $0.24 \mathrm{mmol}$, $4.0 \mathrm{~mol}$ equiv.) and then with methyl iodide $(30 \mu \mathrm{L}, 0.48 \mathrm{mmol}$, $8.0 \mathrm{~mol}$ equiv.) After a further $4 \mathrm{~h}$, the reaction mixture was quenched with $\mathrm{NH}_{4} \mathrm{Cl}$ ( $2 \mathrm{~mL}$ of a saturated aqueous solution) and the separated aqueous phase extracted with dichloromethane $(3 \times 10 \mathrm{~mL})$. The combined organic phases were dried $\left(\mathrm{Na}_{2} \mathrm{SO}_{4}\right)$, filtered, and concentrated under reduced pressure. The lightyellow oil thus obtained was subjected to flash chromatography (silica, $95: 5 \mathrm{v} / \mathrm{v}$, dichloromethane/ammonia-saturated methanol 
elution) and concentration of the appropriate fractions $\left(R_{\mathrm{f}} 0.4\right)$ gave (+)-narseronine $[(+)-2](16.8 \mathrm{mg}, 83 \%)$ as a white, crystalline solid, mp $165-166^{\circ} \mathrm{C}$ [lit. ${ }^{[8]}$ for (-)-enantiomer $\left.167-168^{\circ} \mathrm{C}\right] .[\alpha]_{\mathrm{D}}^{20}+21.0\left(c 0.3, \mathrm{CHCl}_{3}\right)$. Found: $m / z 330.1342$ $(\mathrm{M}+\mathrm{H})^{+} ; \mathrm{C}_{18} \mathrm{H}_{19} \mathrm{NO}_{5}$ requires $330.1341(\mathrm{M}+\mathrm{H})^{+} . \delta_{\mathrm{H}}$ $\left(400 \mathrm{MHz}, \mathrm{CDCl}_{3}\right) 7.67(\mathrm{~s}, 1 \mathrm{H}), 7.28(\mathrm{~s}, 1 \mathrm{H}), 6.13(\mathrm{~m}, 2 \mathrm{H})$, $4.22(\mathrm{t}, J 6.0,1 \mathrm{H}), 3.82($ broad s, $1 \mathrm{H}), 3.57(\mathrm{~s}, 3 \mathrm{H}), 3.07(\mathrm{~m}, 1 \mathrm{H})$, $2.78(\mathrm{~m}, 1 \mathrm{H}), 2.64(\mathrm{~m}, 1 \mathrm{H}), 2.44(\mathrm{~s}, 3 \mathrm{H}), 2.25-2.10$ (complex m, $2 \mathrm{H}), 2.01(\mathrm{~m}, 1 \mathrm{H}), 1.90(\mathrm{~m}, 1 \mathrm{H}) . \delta_{\mathrm{C}}\left(100 \mathrm{MHz}, \mathrm{CDCl}_{3}\right) 161.5$, 10 153.7, 152.7, 148.3, 135.2, 116.4, 108.5, 107.8, 103.3, 102.4, $75.0,62.0,58.2,54.3,42.1,35.0,31.4,29.5 . v_{\max }(\mathrm{KBr}) / \mathrm{cm}^{-1}$ 3449, 2927, 1718, 1623, 1502, 1482, 1413, 1282, 1256, 1161, $1102,1035 . \mathrm{m} / z(\mathrm{ESI},+\mathrm{ve}) 352\left([\mathrm{M}+\mathrm{Na}]^{+}, 8 \%\right), 330([\mathrm{M}+$ $\left.\mathrm{H}]^{+}, 100\right), 298$ (20). The ${ }^{1} \mathrm{H}$ NMR, ${ }^{13} \mathrm{C}$ NMR, and infrared

15 spectral data presented above were in good agreement with those reported for the natural product ${ }^{[7]}$ and for the synthetically derived (-)-narseronine. ${ }^{[8]}$ The only minor discrepancy was observed in the ${ }^{13} \mathrm{C}$ NMR spectra. In particular, the signal reported at $111.5 \mathrm{ppm}$ in the spectrum of the synthetically

20 derived (-)-enantiomer was replaced by one at $108.5 \mathrm{ppm}$ in that of (+)-2. This difference is attributed to the differing acidities of the media in which the samples were analysed.

\section{X-Ray Crystallographic Study}

Crystallographic Data

25 Compound (+)-2

$\mathrm{C}_{18} \mathrm{H}_{19} \mathrm{NO}_{5}, M 329.35, T 150 \mathrm{~K}$, tetragonal, space group $P 4{ }_{1} 2$ 2, Z 8, a 9.0508(2), b 9.0508(2), c 38.9156(17) А, $V$ $3187.85(17) \AA^{3}, D_{x} 1.372 \mathrm{~g} \mathrm{~cm}^{-3}, 3137$ unique data $\left(2 \theta_{\max }\right.$ $\left.146^{\circ}\right), R 0.063$ [for 2832 reflections with $I>2.0 \sigma(I)$ ], $R w$ $30 \quad 0.135$ (all data), $S 1.04$.

\section{Compound 20}

$3\left(\mathrm{C}_{16} \mathrm{H}_{15} \mathrm{NO}_{5}\right) \cdot \mathrm{CH}_{2} \mathrm{Cl}_{2} \cdot \mathrm{CH}_{4} \mathrm{O}, M 1020.87, T 200 \mathrm{~K}$, monoclinic, space group $P 2_{1}, Z 2$, a 10.4126(15), b 14.0062(19), $c$ $15.8996(18) \AA, \beta 103.807(8)^{\circ}, V 2251.8(5) \AA^{3}, D_{x} 1.506 \mathrm{~g} \mathrm{~cm}^{-3}$, 354142 unique data $\left(2 \theta_{\max } 50.2^{\circ}\right), R 0.102$ [for 2507 reflections with $I>2.0 \sigma(I)], R w 0.285$ (all data), $S 1.01$.

\section{Compound 22}

$\mathrm{C}_{16} \mathrm{H}_{15} \mathrm{NO}_{5}, M 301.30, T 200 \mathrm{~K}$, orthorhombic, space group

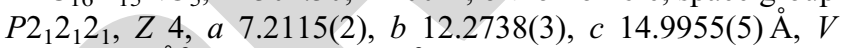
$40 \quad 1327.29(7) \AA^{3}, D_{x} 1.508 \mathrm{~g} \mathrm{~cm}^{-3}, 1764$ unique data $\left(2 \theta_{\max } 55^{\circ}\right)$, $R 0.035$ [for 1543 reflections with $I>2.0 \sigma(I)$ ], $R w 0.084$ (all data), $S 0.99$.

\section{Compound 24}

$\mathrm{C}_{18} \mathrm{H}_{19} \mathrm{NO}_{5}, M 329.35, T 200 \mathrm{~K}$, orthorhombic, space group $45 P 2{ }_{1} 2_{1} 2_{1}, Z$ 4, a 7.9212(7), b 8.8428(8), c 22.4138(19) ̊, $V$ $1570.0(2) \AA^{3}, D_{x} 1.393 \mathrm{~g} \mathrm{~cm}^{-3}, 1615$ unique data $\left(2 \theta_{\max } 50^{\circ}\right)$, $R 0.064$ [for 1109 reflections with $I>2.0 \sigma(I)$ ], $R w 0.137$ (all data), $S 1.08$.

\section{Structure Determination}

50 Images were measured on a Nonius Kappa CCD diffractometer (MoK $\alpha$, graphite monochromator, $\lambda 0.71073 \AA$ ) and data extracted using the DENZO package ${ }^{[18]}$ or an Agilent SuperNova $\mathrm{CCD}$ diffractometer $(\mathrm{CuK} \alpha$, mirror monochromator, $\lambda$ $1.54184 \AA$ ) and data extracted using the Crys Alis package. ${ }^{[19]}$

55 Structure solutions were by direct methods (SIR92). ${ }^{[20]}$ The structures of compounds $(+)-\mathbf{2}, \mathbf{2 0}, \mathbf{2 2}$, and $\mathbf{2 4}$ were refined using the CRYSTALS program package. ${ }^{[21]}$ Atomic coordinates, bond lengths and angles, and displacement parameters have been deposited at the Cambridge Crystallographic Data Centre (CCDC nos. 1020370, 944982, 948651, and 1017935 for compounds (+)-2, 20, 22, and 24, respectively). These data can be obtained free of charge via www.ccdc.cam.ac.uk/data_request/ cif, by emailing data_request@ccdc.cam.ac.uk, or by contacting The Cambridge Crystallographic Data Centre, 12 Union Road, Cambridge CB2 1EZ, UK; fax: +44 1223336033.

\section{Supplementary Material}

The anisotropic displacement ellipsoid plots derived from the single-crystal X-ray structures of compounds (+)-2, 20, 22, and 24 together with ${ }^{1} \mathrm{H}$ and ${ }^{13} \mathrm{C}$ NMR spectra of compounds $(+)-2$, 19, 20, 21, and 22 are available on the Journal's website.

\section{Acknowledgements}

We thank the Australian Research Council and the Institute of Advanced Studies for generous financial support. The very useful ongoing advice provided by Dr Brett Schwartz is gratefully acknowledged.

\section{References}

[1] For key early studies in this area, see: (a) D. T. Gibson, J. R. Koch, R. E. Kallio, Biochemistry 1968, 7, 2653. doi:10.1021/BI00847A031 (b) D. T. Gibson, J. R. Koch, C. L. Schuld, R. E. Kallio, Biochemistry 1968, 7, 3795. doi:10.1021/BI00851A003

(c) D. T. Gibson, V. Subramanian, in Microbial Degradation of Organic Compounds (Ed. D. T. Gibson) 1984, pp. 181-252 (Marcel Dekker: New York, NY).

(d) G. J. Zylstra, D. T. Gibson, J. Biol. Chem. 1989, $264,14940$.

[2] For recent reviews on the production and/or synthetic utility of cis-1,2dihydrocatechols, see: (a) T. Hudlicky, D. Gonzalez, D. T. Gibson, Aldrichim Acta 1999, 32, 35.

(b) R. A. Johnson, Org. React. 2004, 63, 117.

(c) D. R. Boyd, T. D. H. Bugg, Org. Biomol. Chem. 2006, 4, 181. doi:10.1039/B513226F

(d) T. Hudlicky, J. W. Reed, Synlett 2009, 685. doi:10.1055/S-00281087946

(e) T. Hudlicky, J. W. Reed, Chem. Soc. Rev. 2009, 38, 3117. doi:10.1039/B901172M

(f) J. Duchek, D. R. Adams, T. Hudlicky, Chem. Rev. 2011, 111, 4223. doi:10.1021/CR1004138

(g) M. G. Banwell, A. L. Lehmann, R. S. Menon, A. C. Willis, Pure Appl. Chem. 2011, 83, 411. doi:10.1351/PAC-CON-10-10-21

(h) D. J.-Y. D. Bon, B. Lee, M. G. Banwell, I. A. Cade, Chim. Oggi 2012, 30 (No. 5, Chiral Technologies Supplement), 22.

[3] For a useful point of entry into the literature on chemoenzymatic synthesis, see: H. Gröger, ChemCatChem 2011, 3, 239. doi:10.1002/ CCTC. 201100018

[4] The enantiomeric forms (including ent-1) of just a small fraction of the $\sim 400$ known cis-1,2-dihyrocatechols have been reported to date: (a) D. R. Boyd, N. D. Sharma, S. A. Barr, H. Dalton, J. Chima, G. Whited, R. Seemayer, J. Am. Chem. Soc. 1994, 116, 1147. doi:10.1021/JA00082A053

(b) C. C. R. Allen, D. R. Boyd, H. Dalton, N. D. Sharma, I. Brannigan, N. A. Kerley, G. N. Sheldrake, S. C. Taylor, J. Chem. Soc., Chem. Commun. 1995, 117. doi:10.1039/C39950000117

[5] T. Hudlicky, J. D. Price, F. Rulin, T. Tsunoda, J. Am. Chem. Soc. 1990, 112, 9439. doi:10.1021/JA00181A081

[6] (a) M. G. Banwell, C. Chun, A. J. Edwards, M. M. Vögtle, Aust. J. Chem. 2003, 56, 861. doi:10.1071/CH03112

(b) M. G. Banwell, A. J. Edwards, G. J. Harfoot, K. A. Jolliffe, Tetrahedron 2004, 60, 535. doi:10.1016/J.TET.2003.10.122

(c) C. E. Dietinger, M. G. Banwell, M. J. Garson, A. C. Willis, Tetrahedron 2010, 66, 5250. doi:10.1016/J.TET.2010.04.056

25


[7] N. B. Pigni, S. Berkov, A. Elamrani, M. Benaissa, F. Viladomat, C. Codina, J. Bastida, Molecules 2010, 15, 7083. doi:10.3390/ MOLECULES15107083

[8] B. D. Schwartz, M. G. Banwell, I. A. Cade, Tetrahedron Lett. 2011, 52, 4526. doi:10.1016/J.TETLET.2011.06.050

[9] (a) M. T. Jones, B. D. Schwartz, A. C. Willis, M. G. Banwell, Org. Lett. 2009, 11, 3506. doi:10.1021/OL901364N

(b) B. D. Schwartz, M. T. Jones, M. G. Banwell, I. A. Cade, Org. Lett. 2010, 12, 5210. doi:10.1021/OL102249Q

10 [10] D. H. R. Barton, S. W. McCombie, J. Chem. Soc., Perkin Trans. 1 1975, 1574. doi:10.1039/P19750001574

[11] For recent applications of Raney-cobalt in the selective reduction of nitriles, see: (a) S. H. Tan, M. G. Banwell, A. C. Willis, T. A. Reekie, Org. Lett. 2012, 14, 5621. doi:10.1021/OL3026846 (b) T. A. Reekie, M. G. Banwell, A. C. Willis, J. Org. Chem. 2012, 77, 10773. doi:10.1021/JO302132D

[12] L. V. White, B. D. Schwartz, M. G. Banwell, A. C. Willis, J. Org. Chem. 2011, 76, 6250. doi:10.1021/JO201005D

[13] M. G. Banwell, M. T. Jones, T. A. Reekie, B. D. Schwartz, S. H. Tan, L. V. White, Org. Biomol. Chem. 2014, 12, 7433. doi:10.1039/ C4OB00917G

[14] A. L. Gemal, J. L. Luche, J. Am. Chem. Soc. 1981, 103, 5454. doi:10.1021/JA00408A029
[15] For a relevant recent paper dealing with arene hydrates, see: D. R. Boyd, N. D. Sharma, V. Ljubez, P. K. M. McGeehin, P. J. Stevenson, M. Blaine, C. C. R. Allen, Org. Biomol. Chem. 2013 11, 3020. doi:10.1039/C3OB40166A

[16] W. C. Still, M. Kahn, A. Mitra, J. Org. Chem. 1978, 43, 2923.5 doi:10.1021/JO00408A041

[17] A. B. Pangborn, M. A. Giardello, R. H. Grubbs, R. K. Rosen, F. J. Timmers, Organometallics 1996, 15, 1518. doi:10.1021/ OM9503712

[18] DENZO-SMN: Z. Otwinowski, W. Minor, in Methods in Enzymology,

[19] Agilent Technologies, CrysAlisPro Version 1.171.37.33d (release

[20] SIR92: A. Altomare, G. Cascarano, C. Giacovazzo, A. Guagliardi,

[21] P. W. Betteridge, J. R. Carruthers, R. I. Cooper, K. Prout, D. J. Watkin, Volume 276: Macromolecular Crystallography, Part A (Eds C. W. Carter, Jr, R. M. Sweet) 1997, pp. 307-326 (Academic Press: New York, NY). 23-04-2014 CrysAlis171.NET) (compiled 23 April 2014, 17:37:27). M. C. Burla, G. Polidori, M. Camalli, J. Appl. Crystallogr. 1994, $27,435$. J. Appl. Crystallogr. 2003, 36, 1487. doi:10.1107/S0021889803021800

10

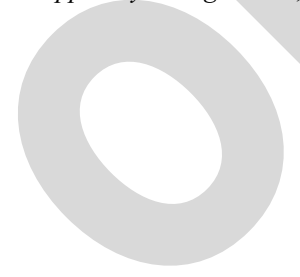

